\title{
Postmodernism, Ethnicity, and Celebrity Culture in Women's Symbolic Consumption
}

\begin{abstract}
While postmodernism and celebrity culture are closely linked, research attention on this has not been adequately synthesised with ethnic minority groups. Hence, this paper, which is rooted in an interpretive research paradigm, explores the symbolic consumption of Black African women in the UK with specific reference to celebrity culture. Although the study shows some purchase decisions based on products' functionality, generally, it shows the robust interplay of personal, cultural, social and commercial factors in the symbolic consumption of these women. This is shown to be linked to the prevalent celebrity culture in the society. They consume to enhance their self-esteem and keep up with the societal trend in the host environment. Hence, the notion of acculturation features prominently in their consumption. The paper extends the discourse on the extant ethnic minority studies and augments the current knowledge about symbolic consumption especially with reference to Black African women.
\end{abstract}

Keywords: Celebrity culture, Women, Symbolic consumption, Black African, Gender, United Kingdom

\section{Introduction}

The connotation of value as a construct in marketing vis-à-vis consumers' choices is not only interesting but could also be enigmatic in the postmodern era. This is because consumption in this day and age plays a myriad of roles in the society and assumes several layers of meaning for various groups of consumers. In the words of Solomon 
(1983), consumption does not occur in a vacuum. It is a significant source of symbolic meanings that are used to sustain our project of the self (Piancetini and Mailer, 2004; Wattanasuwan, 2005; Suarez and Belk, 2017; Bronner \& de Hoog, 2018). At a level, consumers crave for functional attributes of an offering but in several other contexts, consumption could be symbolical. For instance, consumption influenced by celebrity culture as characterized by a plethora of social objects of adoration and adulation is akin to this latter category. Patsiaouras and Fitchett (2012) cite examples of ostentatious display of goods and status consumption as playing key roles in our social relationships. It is not surprising that consumption is described as a key arena of popular culture with significant pedagogical and cultural implications that must be understood by educators (Hoechsmann, 2007; Sandin et al., 2011). So, exploring consumption could be described as a route for understanding human needs, desires, and practices (Perez et al., 2010). Accordingly, the aim of this paper is to explore the symbolic consumption of Black African immigrant women in the UK with specific relevance to celebrity culture.

Meanwhile, a growing body of knowledge argues that the idiosyncrasies of various consumer groups constrain the extent to which we can generalize about existing postulations on how people consume, what they consume, where they buy them, and how often they do so (Nwankwo and Lindridge, 1998; Gbadamosi, 2009; Cleveland et al., 2011; Warden, et al., 2012;.Funches et al., 2017). They note consumers' differences in terms of characteristics such as age, educational status, income, gender, ethnicity, cosmopolitanism, and ethnocentrism.

So, it will be theoretically beneficial to explore symbolic consumption in relation to women in a particular ethnic group as in the focus of this paper. Meanwhile the value of this paper extends beyond this contextual contribution of focusing on women in a particular ethnic 
group (Black African) but extends the discourse on symbolic consumption by linking it to c elebrity culture. This is the gap addressed in this study as highlighted in the aim of the study above.

\section{THEORETICAL BACKGROUND:}

\section{Postmodernism and Symbolic Consumption: A Conceptual Overview}

It is widely acknowledged that consumption's role in the construction of the social world is huge. Postmodernism provides the consumer the opportunity to construct, maintain, and communicate identity and social meaning (Elliot, 1997). In his description of postmodernism, Cova (1996:16) explains it as 'the juxtaposition of contradictory emotions and cognitions regarding perspectives, commitments, ideas and things in general, and consumption in particular, to wit: heterogeneity with uniformity, passive consumption with active customization, individualism with tribalism, fragmentation with globalization, and so on'. Reinforcing this contention from a different perspective, Catterall et al. (2005) argue that postmodernism challenges elitist assumptions and critique the traditional orders, absolute truths, high culture, the commonly acknowledged binary oppositions in language such as male/female and reason/emotion. Put together, these viewpoints corroborate the argument that consumers in the postmodern era are no longer seeking centered, unified character (Firat and Shultz, 1997). They want to feel good in separate, and pursue different moments through the acquisition of self-image that shows them as marketable, desirable, and likeable in each situation (Firat and Shultz, 1997). Accordingly, postmodernism encapsulates a situation characterized with acceptance of different styles, different ways of thinking and different ways of living, and direct response advertising will have some significant roles to play in the marketing communication package (Patterson, 1998). 
Clearly, it could be deduced that women's consumption and postmodernism will be considerably linked especially in relation to the society and its various stakeholders such as the media, and other marketing agencies.

As emphasized by Patternson (1998) consumers need to have their consumption choices reinforced in what could be described as a vote of confidence from other tribe members. The associated state of tension seems to be more heightened by the prevalence of the celebrity brands as linked to celebrity culture in this day and age. Celebrity brands as indicated by Kerrigan et al. (2011: 1506) 'operate as 'map-making', cultural devices, functioning at the level of lifeworld praxis as social forms which embed consumers within networks of immersive resources'. So, through these brands, there is high tendency that the followers' consumptions could be patterned in their social settings. In the words of Elliot (1997), this use of consumption as a resource to create meaning and social transactions involves making choices and could be regarded as existential. Ligas' (2000) claim is that consumers attribute meaning to purchases and this is accompanied by specific goals that he or she intends to fill. This supports the contention of Davies and Elliot (2006) that consumption in recent times revolves around the consumers' happiness and freedom and pressure to consume (Benn, 2004; Davies and Elliot, 2006). So, it could not be limited to the realm of the functional value of the associated offering but should be considered holistically (Stephens et al., 1994; Sirgy and Johar, 1999; Clark et al., 2007; Mann \& Sahni, 2015; Japutra et al., 2018). This is main crux of symbolic consumption. It is defined by Szmigin and Piacentini (2018: 265) as '...the tendency of consumers to rely and focus on the meanings attached to goods, beyond their physical properties, and provide an important means by which consumers define themselves'. Meanwhile, in spite of the myriad of views on women's consumption, 
there is still dearth of studies that specifically focus on the symbolic consumption of Black African women in the UK context. Hence, the focus of this research will not only extend the discourse on women's consumption but does so specifically on a consumer segment that has been described as hard-to reach (Nwankwo et al., 2012).

Quoting Mafesoli (1996), Veloutsou and Moutinho (2009) characterize postmodern communities with instability, small scale nature and not clearly defined by established parameters of modern society. This is reminiscent of meaning beyond the surface which is inherently symbolical. In their work on Supermarkets as libraries of postmodern mythology, Kniazeva and Belk (2010) explored the link between the point-of-purchase brand rhetoric and how consumers read the poetry of packaging. Among others, this study shows that consumers are co-creator of marketplace myths and the process remains open to interpretations by consumers. A closely related theoretical standpoint is evident in Varman and Belk's (2012) study of consuming post-colonial shopping malls. Essentially, they found that young middle-class consumers interpret shopping malls as arenas for identity transformation. It shows that these consumers disguise their Third World realities. In other words, they wear the mask of the West in order to achieve modern and developed identities (Varman and Belk's, 2012). It may be logical to argue that in the postmodern era, women will be producers of symbolic meaning associated with goods and services (Catterall et al., 2005). As argued by Cova (1996), the consumer in this era crafts a customized experience out of the elements of market offerings and attempts to restructure her identity. The synthesis of the foregoing presents a point of convergence that postmodernism is paradoxical, and while the postmodern individual is isolated, he is also in virtual contact with the whole world in various transactions electronically (Cova, 1996b; Laroche et al., 2013; Laroche, 2016). Hence, the postmodern 
consumer creates a customized personal consumption from the elements of the market offerings (Cova and Cova, 2000; Healy and McDonagh, 2013). A closely related contention has been made in the digital world context (Sheth and Solomon, 2014). Nevertheless, we are still left with a considerable gap in the literature in terms of relating this to celebrity culture in the context of Black African women consumers.

\section{Ethnicity, Women's symbolic consumption, and Celebrity Culture: Integrative Perspectives}

The multicultural nature of the developed societies such as the UK and the US becomes increasingly palpable by the day. In a review of the extant literature, Makgosa (2012) identifies a number of factors responsible for this. Among these are high fertility rate, the historical colonial expansion in places like Africa and India, the need to seek employment, have a better living standard, education, and avoidance of political persecution and instability in their home country. Consequently, the purchasing power of these ethnic consumers are increasing and has implications for marketing transactions, especially in terms of their consumption behavior. This is now even more pronounced during this postmodern era. The acknowledgement of this diversity is evident in the suggestion of Demangeot et al. (2013) that effort should be made by multicultural marketplace actors to ensure that consumers of all categories can pursue their universal cultural, economic, and social rights in the system. Meanwhile focusing on women as a specific consumer segment has been a good and fertile research endeavour (Catterall et al., 2005; Gbadamosi, 2012; Xavier et al., 2015). It is argued that the current discourses about women and consumerism show women as special consumers that enact particular disposition, values and behavior (Sandlin and Maudlin, 2012). While a number of reasons can be given to this special interest in women's consumption, some authors have simply emphasized fashion and beauty as very key to this (Martin and Peters, 2005; 
Hume and Mills, 2013).

Considerable evidence shows that the link between women's consumption and beauty cannot be ignored. Virtually every ramification of women's life such as related to hair, eyes, nails, complexion, body size and shape among others are linked to beauty in one way or another. It is stated that to avoid falling into 'the shadows' of a set of elitist social relations, it is now a standard feature that women attempt to make the 'correct choice' (McRobbie, 2008 in Rafferty, 2011). For example, Jantzen (2006) states that women's consumption of underwear might be used for defining a feminine identity by managing bodily presentation in a social life. Consequently, Olivas-Luján et al. (2009: 231) states that 'From the end of nineteenth century through the first decades of the twentieth, Brazilian society attributed to women purity, sweetness, maternity, generosity, spirituality, and patriotism, and made them responsible of all beauty that should impregnate social life'. This explains why advertisers prefer to use female models rather than their male counterpart in their marketing communications messages (Saad, 2004) as shown in a study based on data from the US, China and Thailand (Zang et al., 2009). Moreover, the same study shows that females were portrayed more than men in decorative roles while males were more frequently portrayed than women with regards to recreational roles (Zang et al., 2009). Logically, it can be deduced that there are more than meets the eyes about what women buy, why they buy them, where they them and how often they buy them. Hence, there is a tendency that their purchases and consumption will have some symbolic explications.

Meanwhile, there is far less research that specifically focuses on Black women in the media, rather, the sheer volume of work available is on white women or Black people in general 
(Mastro and Greenberg, 2000; Gordon, 2008). Emphatically, a meticulous search shows a palpable gap in the literature concerning symbolic consumption of Black African women, especially in the UK context. The available information relates mainly to the US-context. As reported concerning the US context, the common portrayal of Black women is found on Black comedies which have attracted criticisms on the ground that they propagate negative images and rely on minstrel-era stereotypes as the basis for their humour (Coleman, 2000). Among these stereotypes of Black African women is sexually promiscuous Jezebel, which is an image popularized to justify the sexual exploitation of Black women during and after slavery (Harris and Hill, 1998; Patton, 2001; Simms, 2001). Supporting this contention, Townsend et al. (2010: p.274) claim that 'although women of other ethnicities have also experienced sexual victimization, the legacy of slavery associates the sexual exploitation of African-American women with distinct dehumanization and degrading practices'. Moreover, there is a claim that colourism may have influence on African-Americans and shape their life experiences (Townsend, et al., 2010; Wilder 2010; Bennett, et al., 2015). The term colourism is used for skin colour stratification of African-American, and has a more significant influence on women (Harris, 2009) as there is a tendency to associate lighter skin with beauty and desirability (Townsend, et al., 2010). Putting all these viewpoints into perspective, it could be argued that individuals within the black culture are differentially influenced by two cultures, the African-American culture and the larger dominant white culture (Helms, 1990; Abrams et al., 1993). This brings in the relevance of consumer acculturation which is about culture change that occurs due to extensive contact between cultural groups (Alvarez et al., 2014). The explication provided by Luedicke (2011) extends this further by exploring the socio-cultural and commercial dynamics associated with migrants moving from one nation to another. He came up with a model which shows that migrants and locals, while constructing their identities, are enmeshed in a complex system of recursive social-cultural adaptation 
which involves various stakeholders within a large system. Corroborating this postulation on the complexity of this phenomenon, Schau et al (2017) show how migrants use native and second languages to make sense of service protocols in the retailscape. Invariably, drawing from this discourse on acculturation and the foregoing, it could be argued that culture, appearance, beauty, and other associated issues could be linked to the individual's selfesteem. It is therefore not surprising that Abrams et al. (1993) found that a young woman who is dissatisfied with her appearance and engaging in severe dietary behaviour is also troubled by low-self-esteem, anxiety, and depression. Meanwhile, the extent to which these findings and contentions apply to Black African women in the UK and their consumption is yet unclear but deserves in-depth research attention.

Meanwhile, the reality of today is that consumers live in a media-saturated world overwhelmed with various visual images. Marketers use celebrity endorsements in various ways to communicate the value of their offerings (Gwinner, 1997; White et al., 2009; Zamudio, C., 2016; Chang and Ko, 2016). At one end of the impact of this strategy on a continuum is the very high positive image and equity of the firm. In this regard, Milne (2009) describes the celebrity as a significant symbolic element in market economies and represents to the audience the process and behaviour of the consumption. An example of this is demonstrated by Wicks et al (2007) who contend that children draw on discourses around celebrities, consumption, commodification, and the spectacular for moral development. Meanwhile, on the other end of the spectrum, everything can also go horribly wrong through 'celebrity trouble factor' or 'celebrity scandal' that can affect the equity of the sponsor. Nevertheless, beyond the repertoire of this celebrity endorsement phenomenon, the celebrity culture has witnessed a dramatic turn in which icons become brands, sustained by technology and use the media for the benefit of her 
own branding (Kerrigan et al., 2011). While the idea of celebrity is not new, its mutation into an important cultural force is a relatively recent development (Furedi, 2010). On this pedestal, celebrity influence could be conceptualized as involving stagings such as celebrity fashion exhibition that work to broaden the appeal of the celebrity as demonstrated through the Kylie Minogue Brand Mythology (Hewer and Hamilton, 2012). A number of celebrity examples across various walks of life such as film stars, celebrity politicians, celebrity lawyers, celebrity scientists, and celebrity academics abound (Furedi, 2010; Brownlie and Hewer, 2011; Driessens, 2013). Alpion (2006) reports about media and celebrity culture around Mother Terasa who was one of the

most publicized $20^{\text {th }}$ century women. Although there are certain issues that differentiate Mother Teresa, the nun, a religious celebrity, from other celebrities; she also used the press and other medium of mass communication to reach out to her intended audience (Alpion, 2006). Citing Marshall (1997: 51), it has been stated that the celebrity figure is a "locus of formative social power in consumer capitalism" (Milnes, 2009). The impact of this celebrity culture is becoming increasingly pronounced. Nonetheless, there are still unanswered questions about the phenomenon when considered in relation to Black African women in the UK. For example, it will be of great value to know the relevance of the prevailing celebrity culture in the consumption behaviour of these women as ethnic consumers in the UK.

\section{Methodology}

This study is rooted in an interpretive research paradigm. As shown in Table 1, a sample of 27 Black African immigrant women drawn from London were interviewed for the study. These semi-structured interviews took place in the respondents' homes as this was the option considered most convenient for them. Given that the data collection and 
analysis are conducted in accordance with the Grounded theory orientation, a theoretical sampling method was used. In the explanation of Strauss and Corbin (1998: 202) which has also been consistently shared in the literature (Silverman, 2000; Denk et al., 2012) it '...means that sampling, rather than being predetermined before beginning the research, evolves during the process'.

Each interview, lasted about one hour, was tape recorded and transcribed for analysis. As the tradition for this approach, the data collection was in tandem with the data analysis, and it continued in that form until when no new ideas were forthcoming the point of theoretical saturation (Strauss and Corbin, 1998; Locke, 2001).

Place Table 1 about here

The data analysis procedure used in this study follows the tradition in the grounded theory approach which comprise: the open coding, the axial coding, and the selective coding (Glaser and Strauss, 1967; Strauss and Corbin, 1998). Open coding which sets the pace for other stages of the process involves conceptualizing, discovering categories, and developing those categories in terms of their properties and dimensions. As done in this study, conceptualizing involves breaking down the data into discrete incidents, ideas, events, and acts and the data are then given a name that represents them. As suggested by Strauss and Corbin (1990), in this present study, at the stage of the open coding, the data that were broken down into discrete parts were closely examined, and compared for similarities and differences.

In this study, the completed open coding of data was followed by axial coding which is the task of relating categories developed to subcategories at the level of their 
properties and dimensions. As explained by Strauss and Corbin (1998) the subcategories answer further questions. Therefore, this linkage of the categories and subcategories reassemble the data that were broken down during the open coding. Thus subcategories gave the concept greater explanatory power. $\mathrm{M}$ icro analysis which includes both open and axial coding was conducted. In this present study, a sentenceby sentence approach was adopted for the microanalysis. The third, selective coding was done. In the description of Spiggle:

\{it\}involves moving to a higher level of abstraction with the developed paradigmatic constructs, specifying relationships, and delineating a core category or constructs around which the other categories and constructs revolve and that relates them to one another (Spiggle, 1994: P495).

In this, the basic tasks are integration, discovering of a central category and refining of the theory. These basic tasks were observed and led to the themes reported in the findings section below.

\section{Summary of findings}

Although in some circumstances, buying products because of their functionality was still reported by the respondents, generally, symbolic consumption is prevalent among them and ranges across many products especially with high involvement products like designer clothes, shoes, bags, cars, and cosmetic products among others. It is also interesting to note respondents' perception of the link between their consumption and the prevailing celebrity culture.

Essentially, a number of factors associated with their symbolic consumption emerged from 
this study. Although the factors that came up are numerous, as indicated in the methodology section, they were pruned down to those presented in Figure 1 below for coherence and clarity in their interpretation. As shown in the figure, the factors have been categorized and discussed under the main themes of Culture, Market offerings, Personal factors, Marketing communications, Social trends, and Economic factors. The impacts of these factors in the symbolic consumption of the women are mediated by the celebrity culture.

Place Figure 1 about here

\section{Culture:}

Findings show that as respondents are in a new cultural environment different from their home countries, the need to be socially relevant in the host cultural environment encourages buying symbolically - acculturation. As reiterated by the respondents, the UK as their host cultural environment, has a good number of celebrities in various aspects of life. Accordingly, by virtue of their achievements and the respect in the society, these celebrities constitute brands themselves through which they influence their followers' consumption decisions for various products. Given that the respondents are closely linked to some of the existing fans of these celebrities based in the UK, they tend to engage in emulative consumption to belong:

I don't think many Black women can deny doing it, but my close friends and I buy what the celebrities are using. It's a lovely experience... when people see it, they know it, and know the value, especially when you talk about fashion...that is the truth (R21, aged 30-39). 
I buy clothes for my esteem. Sometimes, I still do my African attire. It shows me who I am and where I come from. But the UK is a different environment. So, we will have to use fashion stuff that is in vogue. Although people say they are very expensive, but when I hear or know that a celebrity has introduced something, I mean their own brands like perfume or something else, I will buy it, even if it is not immediately (R12, aged 30-39)

Furthermore, respondents also emphasized the significance of their symbolic consumption as a means to combat their experience of cultural stereotypes. As noted by most of the respondents, to be oblivious of the existing celebrity culture in the UK could put them in a 'pigeon hole' of cultural stereotypes. Hence, celebrity culture works positively for them regarding their consumption as it provides direction for 'coping' in a strange cultural environment:

It's like Clinique facial products because I was having quite a lot of breakouts and stuff and so I obviously did a lot of research online which is what I do and... Asked a few people although not a lot of black people that I know would use Clinique, but I think it's one of those things where, because in the UK you find that a lot of products are marketed for, not necessarily people of ethnic backgrounds or you know of dark skin colour or whatever. ...Anyway what I am saying is that doing research will give information on what people are using, say like celebrity stuff (R9, 30-39). 


\section{Personal factors}

The notion of respondents' individuality emerged clearly from the study. The study reveals that, in some instances, the respondents' need to maintain a unique identity among others, like celebrities, direct them to buy certain products. While as individuals in the society, the women buy to feel belonging to other social settings, they are also driven to buy to maintain their individuality. As stated by the respondents, this gives them the opportunity to be pace-setters in some occasions. It boosts their self-confidence and image when they appear in public.

For that reason, I got a bag, like four months ago, I was really, really like upset, personal reasons, and I just went out and I found this bag. It's a really nice orange bag, it's quite nice, Ted Baker, you know nice bag, and I've not touched it, I just look at it and it makes me feel happy (laughs). I've only used it like once, but, because I spent so much on it, I look at it as in that bag will come out on a good day...I know when I use it, it will give me a very good feeling of myself (R18, aged 40-49).

Closely related to this is the respondents' 'self' concept. By this, they have the perception of their desired or 'dream' 'self' which in most cases is different from their 'actual' or 'current' self. Hence, the need to actualize their 'dream self' drives them to buy certain products symbolically:

I don't know. It's always that you get, you know that dress to impress, when you go 
to a party or when you go out... you know you've got to be the bombshell. As soon as you walk in everyone looks, it happens for every girl,... every girl feels that way when they wear something. It's almost like, you dress for yourself, if you feel like you look good, somebody else is going to think like you look good (R13, aged 3039).

I come from a background where I did not have the things that I desired as a teenager growing up as a young girl, but I always had a nice eye for things. So naturally being here when I got to get them I wanted the best like the desire for 800 pairs of shoes (R19, aged 40-49).

Interestingly and paradoxically, this is also mediated by the celebrity culture as these women indicated that with this feeling, they are motivated to follow the consumption tradition of some celebrities who are notably outspoken, clearly distinct, and have what could be described as a courageous personality. Hence, they are interested in maintaining an image of distinctiveness in a society where, as they claimed, it will take courageous living to survive the barrage of products, brands, and marketing communications:

\footnotetext{
Also being in a different social setting here [in the UK] has given me a lot of independence to find who I am for myself. Take it or leave it, that is what I like in some of the celebs in this society (R2, aged 18-29).
} 


\section{Marketing communications}

The role of marketing communications covering factors like branding, social media, and celebrity endorsement came out strongly as a factor that is instrumental to fine-tuning these women's consumption in many ways. As shown in the study, the various marketing communication tools are becoming increasingly used by businesses to make favourable mention of their market offerings to these women who feel encouraged to consume symbolically:

Concerning the question you asked on what persuade me to buy. You know this girl, Rihana, she just came out with her own clothing line and I like the way she dresses. So, seeing the way she dresses and her bringing out a clothing line...I would buy her stuff. I know it is expensive but there is one or two things there that I will definitely buy (R16, aged 40-49)

In other words, they continuously show how these products are beneficial to make the women fulfil their life aspirations. One of the very potent aspects of this influence is the celebrity endorsement. These women indicate that, as respected members of the society, the use of celebrities for endorsing products is pivotal to what they buy and where they buy them. From a broad perspective, these marketing communications further enrich the celebrity culture which also mediates the consumption of these ethnic women in the UK marketing environment:

I think it kinds of go back to advertising again. I mean if it's advertised in a great 
way then you want to feel how that person is feeling in the advert. Like for example, if you see Beyoncé advertising her perfume, you are like oh my God, I want to get her perfume. It's Beyoncé, you want to feel like Beyoncé, you want to feel like a superstar (R20, aged 30-39)

\section{Market offerings}

While women use different types of products on a day-to-day basis, they especially highlight some products as being very significantly symbolic in their purchase. They are basically high-involvement products, mostly endorsed by well-known celebrities and feminine products such as foundation, underwear, perfumes, clothes, and shoes. There are clear overlapping scenarios in this typology as some products fall into both categories. For products in both categories, respondents exhibit conspicuous consumption:

I love taking holidays because it takes me out of this environment. I go on holiday twice a year. I just want to leave my environment and go somewhere new. Although I have issues with the food there, I just like new places...new friends and just enjoy a new experience. (R13, aged 30-39)

Well my hair makes me look good, or people have said. So I buy certain types of hair extensions, to do my hair, hair pomades, hair creams etcetera, and clothes that fit me in a certain way and change my image, the way that I want to look that day (R2, aged 1829). 


\section{Social trends}

The respondents stress the fact that the society has an acceptable standard of living, dressing codes, and modes of appearance. In their words, to live in such a society without matching up will be stressful. This explains why their purchase decisions are tailored to follow after celebrity culture and symbolically indicate that they are relevant in the milieu. There is an acknowledgement of the fact that the media is awash with various developments in the world of fashion. Analysing this view shows how it is closely linked to the respondents' personal factors.

If I buy something nice in this place... with $\mathrm{H} \& \mathrm{M}$, they have these dresses you know the body con dresses, really nice. I like the material. It started with the material from work, the little skirts, the material is nice ...I've just started liking anything they do in H \& M . Then like Punky Fish, they do brighter, rocky things like diamante things, I really like that kind of fashion. Punky Fish has got this little, kind of clothes. They are what many people are using in the society now (R5, aged 18-29)

For example their narratives repeatedly pinpoint the significant role of their self-esteem and social needs in propelling them for symbolic consumption. It became evident that these women see the need to be respected by societal members such as those in their various organizational affiliations, as a key factor for their symbolic consumption. The findings clearly show that respondents know they need to match up with the social trends in order to fulfil these personal aspirations. So, this explains their reason for craving celebrated brands: 
So, I would say I am swayed by reviews... I am less likely to buy something with one star or two stars but if it has 5000 ratings or 5000 buys then I would buy. I normally take note of this trends and what others are saying about things that I will buy (R4, aged 40-49).

\section{Economic factors}

The relevance of the financial commitments associated with their consumption also emerged as a key finding in the study. Although some of these products, such as fashion items are considered expensive, they do not consider this pricing to be a strong inhibitor of their purchase of these products because they consider the value derived from the use of the products as relatively considerable, especially as they show their link to specific celebrities:

it's nice to buy something, .... if I wear a dress, I'm thinking, like I worked four hours for this. It makes you feel good and the other thing I tell myself is when you are angry working and your managers annoying you, it's like think about the shoes you want,... to work again. It gives you that motivation. Seeing what you are working for is nice as well ....it is what you can show people and be proud of (R5, aged 18-29).

I don't have any kid, if I don't buy myself something, who else am I going to buy... for? Yes. Family \{it's good to think about family\}, but what I consider important is how what I buy make me feel than having to bother so much about the price (R7, aged 40-49) 


\section{Discussion}

Evidence in the literature shows that consumers, especially in this age of postmodernism buy certain products because of their symbolic meanings and the roles that the brands play constantly towards helping them to achieve this goal in the self-construction project. In consistency with this line of reasoning, this study shows how Black African women, as a consumer segment in the UK engage in symbolic consumption and are linked to the prevalent celebrity culture. A myriad of factors influence this type of consumption among this consumer segment. The study shows these factors as culture, social trends, and marketing communication. With this, the women claimed that they are confronted with the challenge of the likelihood of being 'pigeon holed' or perceived in a demeaning way in the society if they make no attempt to communicate their relevance in the society. This resonates with the contention of Coleman (2000) and Townsend et al. (2010) about Black African women in the US. It is interesting to report about the UK society where the topic has not been previously empirically explored. Moreover, it is known that there are pressures in the society on the increasing need to be on a par with the societal trend as depicted in the media. Accordingly, this study shows that it becomes increasingly compelling that the women's consumption transcends the threshold where the key factor and decisions lie in the functional attributes of such offerings. This confirms Solomon's (1983) argument that consumption and social behaviour are linked and are at the heart of symbolic consumption but this study extends the reasoning to a distinct consumer group for who there is little data. Meanwhile, the significance of marketing communications tools in the forms of the firms' brands, celebrity endorsement, social media and other tools are noted as very potent in propelling these women to engage in symbolic consumption. The popularity of 
marketing communications to firms in making favourable mention of their various offerings is well acknowledged (Schroeder and Zwick, 2004; Gbadamosi, et al., 2012; Ibroscheva, 2013).

Obviously, this study follows the tradition of previous studies and postulations on self, extended self, brand relationship, and celebrity culture (Elliott, 1997; Belk, 1988; Sirgy and Johar 1999; Kerrigan et al., 2011; and Hewer and Hamilton, 2012) but with a focus on a particular research context towards enriching the existing understanding. It shows the interconnections of personal, commercial, social, and cultural factors as important in how African women consumers in the UK make their consumption decisions. These findings provide explication of consumption decisions which reiterates the view that consumer transactions could not be limited to the scope of functional benefits.

\section{Managerial Implications of the study}

If examined thoroughly, the implications of this study could be explained in two perspectives - theoretical and managerial. From the theoretical perspective, the paper extends the discourse on the extant ethnic minority studies and augments the current knowledge about symbolic consumption especially with a focus on a specific segment of the society. From the managerial standpoint, it is expected that this knowledge could be incorporated into various global marketing programmes especially in the area of marketing communications strategy, and segmentation, targeting and positioning. Evidently, postmodernism is increasingly widening the scope of consumption by the day, especially far beyond the functional benefits associated with the offerings. This 
strengthens the call for marketers, be it at the retailing level or others to follow this trend such that they can address all categories of consumer needs in relation to specific offerings. This will include targeting various consumer groups with appropriate offerings, in relation to the diversity which exists among them in terms of gender and culture in multicultural marketplace.

\section{Limitation of the study and directions for further studies}

Basically, this paper revolves around symbolic consumption of Black African women consumers in the UK. Even though it has shed some light on this focused research domain, it has some notable limitations which make the possible opportunities for future research become apparent. Essentially, the small sample size constrains the extent to which the findings can be generalized to the wider population. However, this does not appear to be very compelling since the study is not positioned to test any pre-defined hypotheses but for constructing a substantive understanding of the researched subjectmatter. Meanwhile, one of the promising avenues for future studies is to explore symbolic consumption of other ethnic groups in the British marketing environment vis-à-vis various demographical variables such as age, income, and educational qualifications. In fact, the topic could also be explored in relation to different product categories. This has the potential to extend the current understanding on the topic.

\section{References}

Abrams, K.K., Allen, L. R. and Cray, J.J, (1993), "Disordered Eating Attitudes and Behaviors Psychological Adjustment and Ethnic Identity: A Comparison of Black and White Female College Students", International journal of Eating Disorders, Vol. 14 No.1, pp. $49-57$ 
Alvarez, C.M.O, Dickson, P. R and Hunter, G. K. (2014), "The four faces of the Hispanic consumer: An acculturation-based segmentation." Journal of Business Research, Vol. 67 No.2, pp. 108-115.

Alpion, G. (2006), "Media and Celebrity culture - Subjectivist, Structuralist and Poststructuralist Approaches to Mother Teresa's Celebrity Status' Continum",: Journal of Media \& Cultural Studies, vol.20 No.4, pp. 541-557

Bartsch, F., Riefler, P. and Diamantopoulos, A., (2016a), A taxonomy and review of positive consumer dispositions toward foreign countries and globalization. Journal of International Marketing, 24(1), pp.82-110.

Bennett, A., Hill, R. P., \& Daddario, K. (2015), "Shopping while nonwhite: racial discrimination among minority consumers", Journal of Consumer Affairs, Vol. 49, No.2, pp. 328-355.

Bronner, F., \& de Hoog, R. (2018). Comparing conspicuous consumption across different experiential products: Culture and leisure. International Journal of Market Research, 1470785318799898.

Brownlie, D. \& Hewer, P. (2009), “Culinary Culture, Gastrobrands And Identity Myths: 'Nigella', An Iconic Brand In the Baking”, Advances In Consumer Research, Vol. 36 No.1, pp.482 - 487.

Brownlie, D. \& Hewer, P. (2011), “(Re)covering' The Spectacular Domestic: Culinary cultures, the feminine mundane and Brand Nigella", Advertising And Society Review, vol.12 No.2,. doi:10.1353/asr.2011.0018

Bryman, A. (2001), Social Research methods, New York; Oxford University press,

Bryman, A. and Bell, E. (2011), Business Research Methods, $3^{\text {rd }}$ edn., Oxford: Oxford University Press

Bulmer, M. (2003), “The Ethics of Social Research”, in Gilbert, N. (ed.), 'Researching Social Life', $2^{\text {nd }}$ ed., London: Sage Publications Ltd., pp.45-57 
Catteral, M., Maclaran, P. and Stevens, L. (2005), "Postmodern Paralysis: The Critical Impasse in Feminist Perspectives on Consumers", Journal of Marketing Management, Vol. 21 No.5-6, pp. 489-504

Chang, Y. and Ko, Y.J., (2016), "Reconsidering the Role of Fit in Celebrity Endorsement: Associative-Propositional Evaluation (APE) Accounts of Endorsement Effectiveness", Psychology \& Marketing, Vol. 33 No.9, pp.678-691.

Clark, R. A., Zboja, J. J., \& Goldsmith, R. E. (2007), “Status consumption and role-relaxed consumption: A tale of two retail consumers", Journal of Retailing and Consumer Services, Vol.14 No.1, pp. $45-59$.

Cleveland, M., Papadopoulos, N. and Laroche, M., (2011),. Identity, demographics, and consumer behaviors: International market segmentation across product categories. International Marketing Review, 28(3), pp.244-266.

Coleman, R. M. (2000), African-American viewers and the Black situation comedy: Situating racial humor. New York: Garland

Cova, B. (1996a) "What postmodern means to Marketing managers", European management Journal. Vol.14 No.5, pp. 494-499

Cova, B. (1996b), "The postmodern Explained to managers: Implications for marketing”. Business Horizons. Vol. 39 No.6, pp.15-23

Demangeot, C., Adkins, N. R., Mueller, R. D., Henderson, R., Ferguson, N. S., Mandiberg, J. M., Roy, A., Johnson, G. D., Kipnis, E., Pullig, C., Broderick, A. J., and Zuñiga, M. A. (2013), “Towards Intercultural Competency in Multicultural Marketplaces”, Journal of Public Policy \& Marketing, Vol. 32 May, pp.156-164

Elliott, R. (1997), "Existential consumption and irrational desire", European Journal of Marketing, Vol.31 No.3, pp. 285-296.

Elliott, R. and Wattanasuwan, K. (1998), "Brands as Symbolic Resources for the 
Construction of Identity", International Journal of Advertising, Vol.17 No.2, 131144

Funches, V., Yarber-Allen, A., \& Johnson, K. (2017), “Generational and family structural differences in male attitudes and orientations towards shopping." Journal of Retailing and Consumer Services, Vol.37 July, pp.101-108.

Fraser, N. and Nicholson, L. (1988), "Social Criticism without Philosophy: An Encounter between Feminism and Postmodernism”, Theory Culture \& Society, Vol. 5 No.2, pp.373- 394

Frie, R. (2011), “Identity, Narrative, and Lived Experience after Postmodernity: Between Multiplicity and Continuity", Journal of Phenomenological Psychology, Vol. 42 No.1, pp.46-60

Firat, A. F. and Shultz II,C,J. (1997) "From segmentation to Fragmentation Markets and marketing strategy in the postmodern era”, European Journal of Marketing, Vol. 31 No.3/4, pp.183-207.

Gakhal, B. and Senior, C. (2008), "Examining the influence of fame in the presence of beauty: an electrodermal 'neuromarketing' study", Journal of Consumer Behaviour, Vol. 7 No.4-5, pp.331-3411

Gbadamosi, A. (2009), "Cognitive dissonance: The implicit explication in low-income consumers' shopping behaviour for 'low-involvement' grocery products", International Journal of Retail and Distribution Management, Vol. 37 No.12, pp. 1077-1095

Gbadamosi, A. (2012), “Acculturation: An Exploratory Study of Clothing Consumption among Black African Women in London (UK)", Journal of Fashion Marketing and Management, Vol. 16 No.1, pp.5-20

Glaser, B. and Strauss, A. (1967), The Discovery of Grounded Theory, Chicago: Aldine 
Publishing

Goulding, C (2003),"Issues in representing the postmodern consumer", Qualitative Market Research: An International Journal, Vol. 6 No.3, pp. 152 - 159

Gordon, M. K. (2008), "Media Contributions to African American Girls' Focus On Beauty and Appearance: Exploring the Consequences of Sexual Objectification”, Psychology of Women Quarterly, Vol.32 No.3, pp. 245-256

Gwinner, K., (1997), A model of image creation and image transfer in event sponsorship. International marketing review, 14(3), pp.145-158.

Hamouda, M. (2012), “ Postmodernism and Consumer Psychology: Transformation or Break?", International Journal of Academic Research in Business and Social Sciences, Vol. 2 No. 1, p 96-117

Harris, T. M., \& Hill, P. S. (1998), "Waiting to exhale" or "Breath(ing) again": A search for identity, empowerment, and love in the 1990s". Women and Language, Vol.11 No.2, pp. 9-20.

Healy, J.C. and McDonagh. P. (2013), "Consumer roles in brand culture and value cocreation in virtual communities”. Journal of Business Research. Vol. 66 No. 9, pp. 1528-1540.

Helms, J, E. (1990), Black and white racial identity: Theory, research and practice. New York: Greenwood Press

Hewer, P. and Brownlie., D. (2013), "Spaces of hope, enlivenment and entanglement: Explorations in the spatial logic of celebrity culinary brands", Journal of Consumer Culture, Vol.13 No.1, pp. 46-63.

Hewer, P. and Hamilton, K. (2012), "Exhibitions and the role of fashion in the sustenance of the Kylie Brand mythology: unpacking the spatial logic of celebrity culture", Marketing Theory, Vol. 12 No.4, pp. 411-425 
Hume, M. and Mills, M. (2013), “Uncovering Victoria's Secret: Exploring Women's Luxury Perceptions of Intimate Apparel and Purchasing behaviour", Journal of Fashion Marketing and Management: An International Journal, Vol. 17 No. 4, pp. $460-485$

Jantzen, C. (2006), “Becoming a 'Woman to the Backbone' Lingerie consumption and the experience of feminine identity", Journal of Consumer Culture, Vol 6 No,2, pp.177-202

Japutra, A., Ekinci, Y. and Simkin, L., (2018). Positive and negative behaviours resulting from brand attachment: The moderating effects of attachment styles. European Journal of Marketing. European Journal of Marketing, Vol. 52 Issue: 5/6, pp.1185-1202,

Joy, A., Sherry Jr, J. F., Troilo, G., \& Deschenes, J. (2010), “ Re-thinking the relationship between self and other: Levinas and narratives of beautifying the body". Journal of Consumer Culture, Vol.10 No.3, pp. 333-361

Kerrigan, F., Brownlie, D., Hewer, P. \& Daza - LeTouze, C. (2011), “Spinning' Warhol: Celebrity Brand theoretics and the logic of the celebrity brand". Journal of Marketing Management, Vol. 27, No.13 - 14, pp.1504 - 1524

Kniazeva, M. and Belk, R. W. (2010), "Supermarkets as libraries of postmodern mythology”, Journal of Business Research. Vol. 63 No.7, pp. 748-753

Laroche, M. (2016), "Advancing knowledge of the global consumer culture: Introduction to the special issue, Journal of Business Research, 69,: 1071-1073

Laroche, M., Habibi, M.R., \& Richard, M.O. (2013), To be or not to be in social media: How brand loyalty is affected by social media. International Journal of Information Management, 33(1), 76-82.

Luedicke, M. K. (2011), “Consumer acculturation theory :(crossing) conceptual boundaries”, Consumption Markets \& Culture, Vol. 14 No.3, pp.223-244. 
Ligas, M. (2000), "People, products and pursuits: Exploring the relationship between consumer goals and product meaning", 'Psychology \& Marketing; Vol.17 No.11, pp. $983-1003$

Lupton, D. (1994), "Consumerism, commodity culture and health promotion". Health promotion international. Vol. 9, No.2, pp. 111-118

Martin, M, C, and Peters, C. O. (2005), 'Exploring adolescent girls' identification of beauty types through consumer collages", Journal of Fashion Marketing and Management, Vol. 9 No. 4, pp. 391-406

Makgosa, R. (2012), "Ethnic diversity in Britain: a stimulus for multicultural marketing", Marketing Intelligence \& Planning, Vol. 30 No. 3, pp. 358 - 378

Mann, B. J. S., \& Sahni, S. K. (2015). Exploring the drivers of status consumption for the wedding occasion. International Journal of Market Research, 57(2), 179-202.

Manel H. and Abderrazak G. (2013), “ The Postmodern Consumer: An Identity Constructor?”, International Journal of Marketing Studies; Vol. 5 No, 2, pp. 41

Mastro, D. E., \& Greenberg, B. S. (2000), "The portrayals of racial minorities on prime-time television", Journal of Broadcasting and Electronic Media, Vol. 44 No.4, pp. 690703.

Milne, E. (2009), “FCJ-104 Materialities of Law: Celebrity Production and the Public Domain", The Fibreculture Journal: No.15

Nwankwo, S. and Lindridge, A. (1998), “Marketing to ethnic minorities in Britain”, Journal of Marketing Practice: Applied Marketing Science, Vol.4 No,7, pp. 200-16.

Nwankwo, S., Akunuri, J., and Madichie, N.O., (2010), "Supporting black businesses: narratives of support providers in London", International Journal of Behaviour and Research, Vol. 16 No.6, pp. 561-580 
Olivas-Luján, M. R., Monserrat, S. I., Ruiz-Gutierrez, J. A., Greenwood, R. A., Gómez , S. M., Murphy, Jr., E. F., and Santos, N. M. B. F. (2009), "Values and attitudes towards women in Argentina, Brazil, Colombia and Mexico", Employee Relations, Vol. 31 No. 3, pp.227-244

Park, S. P. and Lee, E, M. (2005), "Congruence between Brand Personality and SelfImage, and the Mediating Roles of Satisfaction and Consumer-Brand Relationship on Brand Loyalty", Asia Pacific Advances in Consumer Research, Vol.6: pp.39-45

Patsiaouras, G., \& Fitchett, J. A. (2012), “The evolution of conspicuous consumption”. Journal of Historical Research in Marketing, Vol. 4 No.1, pp.154176

Patterson, M. (1998), "Direct Marketing in Postmodernity: Neo-tribes and Direct Communication”, Marketing Intelligence and Planning, Vol. 16 No.1, pp. 68-74

Patton, T. O. (2001), “Ally McBeal and her homies: The reification of White stereotypes of the other" Journal of Black Studies, Vol. 32 No.2, pp.229-260.

Perez, M, E. Castano, R. and Quintanilla, C. (2010), "Constructing identity through the consumption of counterfeit luxury goods", Qualitative Market Research: An International Journal, Vol.13 No.3, pp. 219-235

Piancetini, M. and Mailer, G. (2004), “Symbolic Consumption in Teenagers' Clothing Choices", Journal of Consumer Behaviour, vol.3, No.3, pp.251-262

Rafferty, K. (2 0111 ), "Class-based emotions and the allure of fashion consumption", Journal of Consumer Culture, Vol.11, No.2, pp. 239-260

Saad, G. (2004), “Applying Evolutionary Psychology in Understanding the Representation of Women in Advertisements", Psychology \& Marketing, Vol.21 No.8, pp. 593-612

Sandlin, J. A. Maudlin, J,G. (2012), “Consuming pedagogies: Controlling images of 
women as consumers in popular culture". Journal of Consumer Culture, Vol. 12 No.2, pp. 175-194

Schau, H J, Dang, Y. M. and Zhang, Y. G. (2017), "Learning to navigate the American retail servicescape: Online forums as consumer acculturation platforms and consumer gift systems." Journal of Business Research, Vol. 72 March, pp. 178-188.

Sheth, J. N., \& Solomon, M. R. (2014), "Extending the extended self in a digital world”. Journal of Marketing Theory and Practice, Vol.22 No.,2, pp. 123-132.

Solomon, M. R ( 1983), "The Role of Products as Social Stimuli: A Symbolic Interactionism Perspective", Journal of Consumer Research, Vol.10 No.3, pp.319329 ,

Stephens, D. L., Hill, R. P., \& Hanson, C. (1994), “The beauty myth and female consumers: The controversial role of advertising". The Journal of Consumer Affairs, Vol.28 N0.1, pp. 137-153.

Suarez, M. and Belk, R., (2017), Cultural resonance of global brands in Brazilian social movements. International Marketing Review, 34(4), pp.480-497.

Szmigin, I and Piacentini, M. (2018), 'Consumer Behaviour', 2 ${ }^{\text {nd }}$ ed, Oxford: Oxford University Press

Townsend, T. G., Thomas, A. J., Neilands, T. B. and Jackson, T. R. (2010), “I'm No Jezebel; I Am Young, Gifted, and Black: Identity, Sexuality, and Black Girls”, Psychology of Women Quarterly, Vol. 34 No.3, pp. 273-285.

Veloutsou, C . and Moutinho, L . (2009), “Brand relationships through brand reputation and brand tribalism". Journal of Business Research, Vol. 62 No.3, pp. 314-322

Warden, C. A., Stanworth, J., Chen, J. F., \& Huang, S. C. T. (2012). Strangers in strange lands: Hypermarkets and Chinese consumer culture misalignment. International 
Journal of Market Research, 54(6), 799-820.

Wilder, J. (2010), "Revisiting "Color Names and Color Notions": A Contemporary Examination of the Language and Attitudes of Skin Color among Young Black Women", Journal of Black Studies, Vol. 41 No.1, pp. 184-206

Webster, E (2006), “Symbolic Consumption: Dressing for Real and Imagined Space, Textile": The Journal of Cloth \& Culture, Vol.4 No.2, pp. 164-182,

Wicks, P. G., Nairn, A. and Griffin, C. (2007), "The Role of Commodified Celebrities in Children's Moral Development: The Case of David Beckham", Consumption Markets and Culture, Vol.10 No.4, pp. 401-424

Wyatt, R. J., Gelb, B. D. and Geiger-Oneto, S. (2008), "How Social Insecurity and the Social Meaning of Advertising Reinforce Minority Consumers' Preference for National Brands", Journal of Current Issues and Research in Advertising, Vol.30 No.1, pp. 61-70

Xavier, J.M., Moutinho, V.M. and Moreira, A.C.,(2015), "Efficiency and convergence analysis in women's clothing retail store chain: Evidence from Portugal”, International Journal of Retail \& Distribution Management, Vol. 43 No.9, pp.796-814.

Zamudio, C., (2016), "Matching with the stars: How brand personality determines celebrity endorsement contract formation", International Journal of Research in Marketing, Vol. 33 No.2, pp.409-427. 
Table 1: Demographics

\begin{tabular}{|c|c|c|c|c|c|}
\hline Respondents & $\begin{array}{l}\text { Age } \\
\text { Category }\end{array}$ & $\begin{array}{l}\text { Marital } \\
\text { Status }\end{array}$ & $\begin{array}{l}\text { Annual } \\
\text { Income } \\
\text { Per annum }\end{array}$ & $\begin{array}{l}\text { Educational } \\
\text { Qualification }\end{array}$ & Years of Stay \\
\hline R1 & $30-39$ & married & $£ 12001-20000$ & First Degree & $\begin{array}{l}5 \text { years and } \\
\text { more }\end{array}$ \\
\hline R2 & $18-29$ & Single & $£ 12001-20000$ & A levels & $\begin{array}{l}5 \text { years and } \\
\text { more }\end{array}$ \\
\hline $\mathrm{R} 3$ & $18-29$ & Single & Below $£ 12000$ & GCSE & $\begin{array}{l}\text { Between } 3 \\
\text { and } 5 \text { years }\end{array}$ \\
\hline $\mathrm{R} 4$ & $40-49$ & Married & $£ 20000-30000$ & First Degree & $\begin{array}{l}5 \text { years and } \\
\text { more }\end{array}$ \\
\hline $\mathrm{R} 5$ & $18-29$ & Single & Below $£ 12000$ & First Degree & $\begin{array}{l}5 \text { years and } \\
\text { more }\end{array}$ \\
\hline R6 & $18-29$ & Single & Below $£ 12000$ & First Degree & $\begin{array}{l}5 \text { years and } \\
\text { more }\end{array}$ \\
\hline R7 & $40-49$ & Single & $£ 20000-30000$ & First Degree & $\begin{array}{l}5 \text { years and } \\
\text { more }\end{array}$ \\
\hline $\mathrm{R} 8$ & $40-49$ & Widowed & $£ 12001-20000$ & GCSE & $\begin{array}{l}5 \text { years and } \\
\text { more }\end{array}$ \\
\hline R9 & $30-39$ & Single & $£ 20000-30000$ & First Degree & $\begin{array}{l}5 \text { years and } \\
\text { more }\end{array}$ \\
\hline R10 & $18-29$ & Single & $£ 12001-20000$ & First Degree & $\begin{array}{l}5 \text { years and } \\
\text { more }\end{array}$ \\
\hline R11 & $40-49$ & Married & Below $£ 12000$ & First Degree & $\begin{array}{l}5 \text { years and } \\
\text { more }\end{array}$ \\
\hline R12 & $30-39$ & Single & $£ 20001-30000$ & Masters Degree & $\begin{array}{l}5 \text { years and } \\
\text { more }\end{array}$ \\
\hline R13 & $30-39$ & Single & $£ 30001-40000$ & Masters Degree & $\begin{array}{l}5 \text { years and } \\
\text { more }\end{array}$ \\
\hline R14 & $30-39$ & Widowed & $\begin{array}{l}\text { Below } \\
£ 12001-20000\end{array}$ & First Degree & $\begin{array}{l}\text { Between } 3 \\
\text { and } 5 \text { years }\end{array}$ \\
\hline $\mathrm{R} 15$ & $18-29$ & Single & $\begin{array}{l}\text { Below } \\
£ 12001-20000\end{array}$ & $\begin{array}{l}\text { GCSE } \\
\text { Access to social } \\
\text { work }\end{array}$ & $\begin{array}{l}5 \text { years and } \\
\text { more }\end{array}$ \\
\hline R16 & $40-49$ & Married & $£ 20001-30000$ & First Degree & $\begin{array}{l}5 \text { years and } \\
\text { more }\end{array}$ \\
\hline $\mathrm{R} 17$ & $30-39$ & Married & $\begin{array}{l}\text { More than } \\
£ 50000\end{array}$ & Masters Degree & $\begin{array}{l}5 \text { years and } \\
\text { more }\end{array}$ \\
\hline R18 & $40-49$ & Single & $£ 30001-40000$ & First Degree & $\begin{array}{l}5 \text { years and } \\
\text { more }\end{array}$ \\
\hline R19 & $40-49$ & Married & $£ 30001-40000$ & First Degree & $\begin{array}{l}5 \text { years and } \\
\text { more }\end{array}$ \\
\hline $\mathrm{R} 20$ & $30-39$ & Divorced & $£ 30001-40000$ & Masters degree & $\begin{array}{l}5 \text { years and } \\
\text { more }\end{array}$ \\
\hline R21 & $30-39$ & Married & $£ 20001-30000$ & First degree & 5 years and \\
\hline
\end{tabular}




\begin{tabular}{|c|c|c|c|c|c|}
\hline & & & & & more \\
\hline R22 & $30-39$ & Single & $\begin{array}{l}\text { Below } £ 12000 \\
\text { per annum }\end{array}$ & GCSE & $\begin{array}{l}5 \text { years and } \\
\text { more }\end{array}$ \\
\hline R23 & $40-49$ & Married & $\begin{array}{l}£ 20001-30000 \\
\text { per annum }\end{array}$ & $\begin{array}{l}\text { Higher national } \\
\text { diploma }\end{array}$ & $\begin{array}{l}5 \text { years and } \\
\text { more }\end{array}$ \\
\hline R24 & $50-59$ & Widowed & $\begin{array}{l}\text { More than } \\
£ 50000\end{array}$ & First Degree & $\begin{array}{l}5 \text { years and } \\
\text { more }\end{array}$ \\
\hline $\mathrm{R} 25$ & $50-59$ & Married & $£ 30001-40000$ & GCSE & $\begin{array}{l}\text { Between } 3 \\
\text { and } 5 \text { years }\end{array}$ \\
\hline R26 & $60-69$ & Widowed & $\begin{array}{l}£ 20001-30000 \\
\text { per annum }\end{array}$ & First degree & $\begin{array}{l}5 \text { years and } \\
\text { more }\end{array}$ \\
\hline $\mathrm{R} 27$ & $60-69$ & Divorced & $\begin{array}{l}£ 20001-30000 \\
\text { per annum }\end{array}$ & GCSE & $\begin{array}{l}5 \text { years and } \\
\text { more }\end{array}$ \\
\hline
\end{tabular}

Figure 1 : Black African Women and Symbolic Consumption 


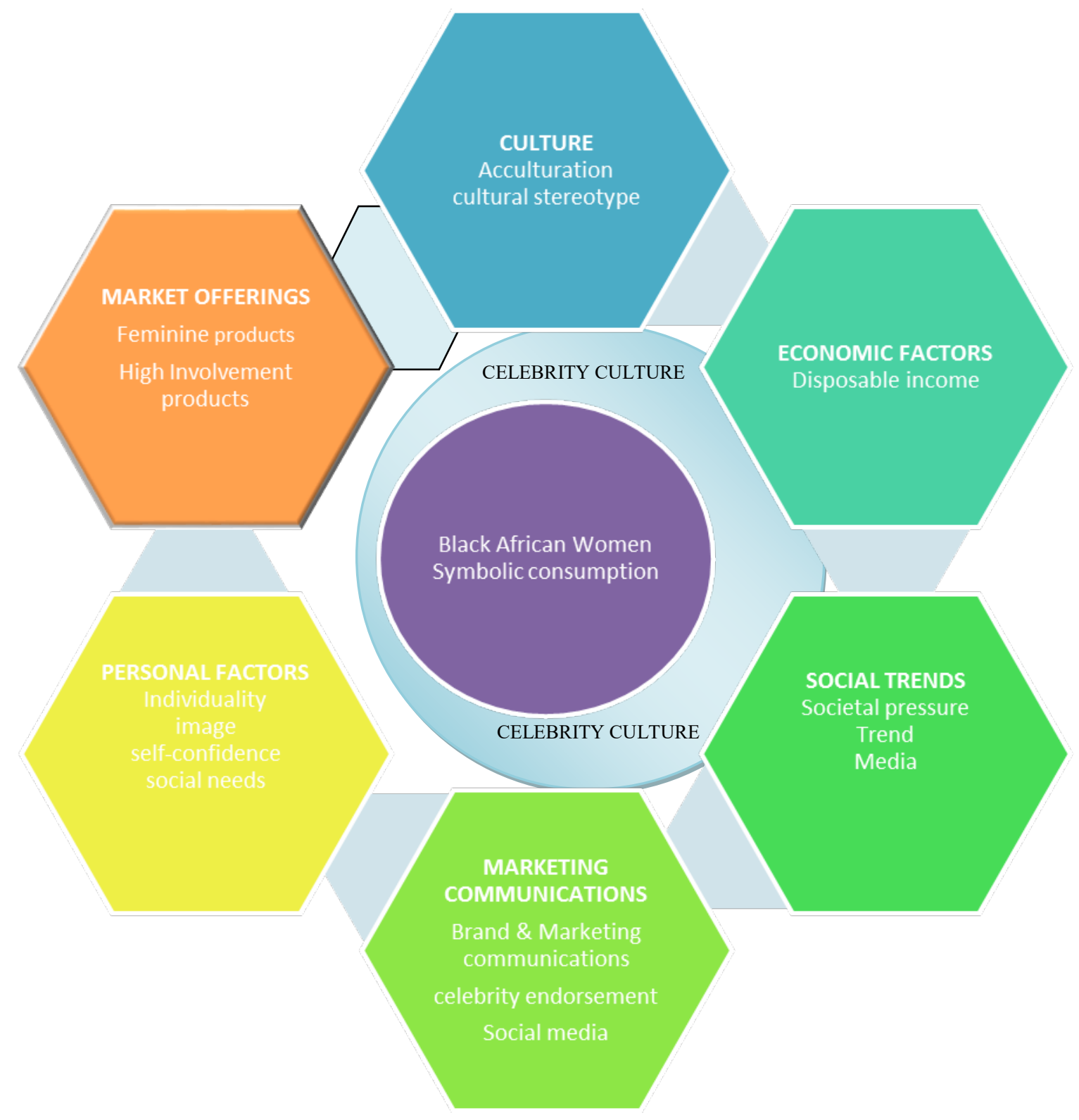

